\title{
The usefulness of sulfur fertilizers for balanced nutrition of spring wheat on zonal soils of the south-western Forest steppe zone
}

\author{
L. V. Levshakov* \\ Kursk State Agricultural Academy named after I. I. Ivanov, Kursk, Russian Federation
}

\begin{abstract}
The importance of sulfur for a balanced nutrition of grain crops is demonstrated. The content of mobile forms of sulfur in the main zonal soils of the Kursk region - black soil and gray forest soils is given. Gray wooded soils have a low content of mobile sulfur in most areas of the region. The availability of sulfur in black soil ranges from low to medium. Practical studies on the effectiveness of different types and forms of using sulfurcontaining mineral fertilizers in the cultivation of spring wheat on zonal types of soils in the south-western forest steppe of the Central Black Earth Region have been performed. Research has found that the practicability of using sulfur-containing mineral fertilizers and their agronomic effectiveness is directly associated with the content of available forms of sulfur in the arable layer of the soil. It is most effective and reasonable to use sulfurcontaining mineral fertilizers in the cultivation of spring wheat on gray wooded soils. The practical data obtained prove the urgency of the use of sulfur-containing fertilizers in technologies for the cultivation of grain crops on soils with inadequate content of available forms of sulfur.
\end{abstract}

\section{Introduction}

In modern technologies of cropping, in order to obtain the highest possible productivity, it is required to fully provide them with the necessary nutrients of nutrition during the growing season. Since most of the plant nutrients are absorbed and digested from the soil, the condition for obtaining high crop productivity is the accessibility of affordable forms of macro- (nitrogen, phosphorus, potassium), meso-(sulfur, calcium, magnesium) and micronutrients (boron, molybdenum, copper, zinc, etc.) in the soil [1]. Meanwhile, in recent years, more and more attention has been paid to meso- and micronutrients [2]. In order for plants to survive, they are needed in very small quantities. Their content in agricultural crops often varies in the range of hundredths to thousandths of a percent of the plant mass. Nevertheless, in spite of their very small content, each of these nutrients in the plant body performs exactly defined functions and is actively involved in the processes of metabolism, balanced nutrition of plants and cannot be substituting for another nutrient under any circumstances. It is found that the lack of meso- and micronutrients accessible for plant

\footnotetext{
* Corresponding author: leo-levshakov@yandex.ru
} 
nutrition in soils results in a significant decrease in the yield of these crops. They become more vulnerable to various pathogens and diseases [3]. The balanced diet of most cultivated crops has been increasingly concentrated on sulfur in recent years [4]. It refers to mesonutrients. It is a part of various protein compounds in the plant body, such as amino acids (cystine, cysteine, etc.); separate non-protein compounds, for example, glucosides, and is an indispensable nutrient of various enzymes and vitamins [5]. The research carried out by leading Russian [6] and foreign scientists [7] in recent years demonstrates the increasingly significant role of this nutrient in the development of highly productive agrocenoses and its polyfunctional role in the biological and physiological processes occurring in plants. This indicates that in the technologies of modern highly productive agriculture, the use of sulfurcontaining fertilizers is becoming an obligatory agrotechnical technique.

The plants absorb most of the sulfur from the soil. It is found in the form of inorganic compounds, most often represented by sulfates (gypsum CaSO4*2H2O, anhydride CaSO4) and sulfides (pyrite FeS2). Virtually most of the sulfur in the humus layer of most zonal Forest steppe soils (up to $90-93 \%$ ) is presented by various protein compounds or organic residues that are from the organic part of the soil - humus. This sulfur is not accessible for plant nutrition [8]. The analysis of the data collected as a result of the agrochemical survey of the soil cover of the Kursk region showed a clear pattern of decreasing the content of various forms of sulfur in both black and gray wooded soils [9]. The main grounds for this are the following:

- high yield and high sulfur removal by agricultural crops;

- inadequate replacement of soils with this nutrient by the introduction of sulfur-containing mineral fertilizers;

- low content of organic matter in the soil, which results in a decrease in the total sulfur reserves;

- a considerable reduction in the use of organic fertilizers and sulfur-containing industrial waste.

According to the data of the agrochemical survey conducted in the Kursk region over the past 10 years, the lowest content of all forms of sulfur (including those accessible for plant nutrition) is typical for gray wooded soils of various subtypes, which have low agrochemical indicators of soil fertility and a light granulometric composition. Consequently, more than 96 $\%$ of the arable area of gray wooded soils has a low sulfur content, $3.5 \%$ - high and $0.2 \%$ medium. Black soils of all subtypes belong to ones that are quite well provided with many micro and mesonutrients, including sulfur [2]. However, today, the established agricultural practice indicates an increasingly noticeable trend of reducing the content of mobile sulfur in these soils. Sulfur in modern food systems of grain crops is becoming one of the most essential nutrients, without which it is impossible to obtain maximum productivity. When there is a lack of sulfur in the complex mineral nutrition of spring wheat, the processes of photosynthesis are slowed down, plant growth is suppressed, small heads are formed, and the maturation of plants is delayed, which considerably affects the yield [10]. For this reason, it becomes practically impossible to achieve a consistently high productivity of almost all agricultural crops, including spring wheat, without the use of sulfur-containing fertilizers [11].

It should be mentioned that at present, a wide range of mineral fertilizers, both domestic and foreign, is manufactured, containing in their composition, among other macronutrients, sulfur in the forms available to plants. Special water-soluble sulfur-containing fertilizers for use on the leaf surface are of great practical interest. Nevertheless, the effectiveness of their use is largely governed by the soil and climatic conditions, the peculiarities of the applied nutrition systems, the standards and methods of application of sulfur-containing mineral fertilizers [12]. On the basis of the above, the study of practical methods, techniques and standards for the application of sulfur-containing fertilizers in the cultivation of spring wheat in the 
conditions of the south-western Forest-steppe of the Central Black Earth Region is an acute and important technological method for increasing the maximum productivity of this crop.

\section{Materials and methods}

Purpose of the research is - is to establish the practicability of using sulfur-containing mineral fertilizers in the cultivation of spring wheat on zonal soils of the Forest-steppe zone with different content of mobile forms of sulfur.

Practical field tests on the effectiveness of the use of sulfur-containing mineral fertilizers were performed on black soil typical in the conditions of Kursk Federal Agricultural Research Center (Basic Department of the Kursk State Agricultural Academy named after I. I. Ivanov) and dark gray wooded soils at "Znamenskoe" OOO of the Rylsky district of the Kursk region.

1. Control - without fertilizers;

Scheme of field tests:

2. Ammonium sulfate, in the spring before sowing, at a dose of $2 \mathrm{c} / \mathrm{ha}$;

3. Ammonium nitrate, in the spring before sowing at a dose of $1.15 \mathrm{c} / \mathrm{ha}$;

4. YaraVita THIOTRAC 300 - on the leaf surface during the growing season, $31+31$, boot stage and milky stage;

5. Complex fertilizer (10-20-20-6) in the fall for plowing at a dose of $2 \mathrm{c} / \mathrm{ha}+$ ammonium nitrate in the spring before sowing at a dose of $0.65 \mathrm{c} / \mathrm{ha}$;

6. Complex fertilizer (10-20-20-6) in autumn for plowing at a dose of $3 \mathrm{c} / \mathrm{ha}+$ ammonium nitrate in spring before sowing at a dose of $0.9 \mathrm{c} / \mathrm{ha}$;

7. Complex fertilizer (16-16-16) in autumn for plowing at a dose of $2.5 \mathrm{c} / \mathrm{ha}$;

8. Complex fertilizer (16-16-16) in autumn for plowing at a dose of $3.75 \mathrm{c} / \mathrm{ha}$.

In the study, the traditional methods used in performing such field experiments were used: the repetition was three-fold, the variants were arranged systematically in one level. The total area of the plot is $120 \mathrm{~m}^{2}$, the total area is $100 \mathrm{~m}^{2}$.

Field tests with sulfur-containing fertilizers were performed in conformance with the current meteorological conditions and agricultural machines provided by these research and manufacturing organizations. The spring wheat variety Darya with a seeding rate of 5.0 million tons grains per hectare was used.

In the course of field tests, phenological observations, selection and analysis of soil samples at the beginning and end of the growing season, the degree of disease spread, and other related surveys were conducted in accordance with generally accepted methods. Before harvesting, the composition of the spring wheat crop was assessed by selecting sheaf samples from an area of $0.25 \mathrm{~m}^{2}$ from each plot. The number of plants per square meter, total and tilling capacity were assessed. Soil samples were analyzed in the research center of the Kursk State Agricultural Academy and in the laboratory of Agrochemical Service Center "Kurskaya". In defining the agrochemical indicators, we used generally accepted laboratory methods for black soils and gray wooded soils.

A Sampo-1200 self-propelled combine was used for harvesting experimental plots of spring wheat. The resulting crop was recalculated immediately after harvesting directly on the spot, accounting for the correction for one hundred percent purity and 14\% moisture content of the grain. The qualitative characteristics of grain were assessed in the laboratory of the Department of Technology of Production and Processing of Agricultural Goods using standard methods [13]. 


\section{Results and discussion}

In accordance with the data of the agrochemical survey (2019), the arable soils of the Kursk region have a different content of macro-, meso- and micronutrients. For black soils (about $74 \%$ of the arable land area) are characterized by a higher content of macronutrients and most micronutrients [1]. They are marked by a lower content of organic matter and increased soil acidity, Table 1 . In gray wooded soils ( $24.5 \%$ of the arable land area), there is a lower content of macro-and micronutrients. They are marked by a lower content of organic matter and increased soil acidity. This is mainly due to the features of the soil-forming process occurring in these soils. Gray wooded soils are also marked by a lower content of mobile forms of sulfur compared to black soils.

Table 1. Agrochemical indicators of soil crop-producing power of experimental plots (averaged data from 2018 to 2020).

\begin{tabular}{|l|c|c|}
\hline \multirow{2}{*}{ Feature } & \multicolumn{2}{|c|}{ Value } \\
\cline { 2 - 3 } & typical black soils & dark gray wooded soils \\
\hline Soil organic matter, \% & 5.9 & 3.1 \\
\hline $\mathrm{pH}$ & 6.1 & 5.1 \\
\hline $\mathrm{N}, \mathrm{mg} / \mathrm{kg}$ & 168 & 98 \\
\hline $\mathrm{P}_{2} \mathrm{O} 5, \mathrm{mg} / \mathrm{kg}$ & 148 & 123 \\
\hline $\mathrm{K}_{2} \mathrm{O}, \mathrm{mg} / \mathrm{kg}$ & 121 & 111 \\
\hline $\mathrm{B}, \mathrm{mg} / \mathrm{kg}$ & 0.37 & 0.33 \\
\hline $\mathrm{Cu}, \mathrm{mg} / \mathrm{kg}$ & 0.29 & 0.06 \\
\hline $\mathrm{Zn}, \mathrm{mg} / \mathrm{kg}$ & 0.32 & 0.4 \\
\hline $\mathrm{Mg}, \mathrm{mg} / \mathrm{eq}$. / to $100 \mathrm{~g}$ & 4.6 & 3.9 \\
\hline $\mathrm{S}, \mathrm{mg} / \mathrm{kg}$ & 7.5 & 2.9 \\
\hline
\end{tabular}

The data of agrochemical analyses in the survey of the soils of the Kursk region showed that about $96 \%$ of arable land in gray wooded soils and about $85 \%$ of black soil have a low content of sulfur and practically all cultivated crops are short of and severely deficient in sulfur.

Typical black soils of the experimental area are characterized by a heavy-loamy granulometric composition with an average organic matter content of $5.9 \%$, an average content of easily hydrolyzed nitrogen of 16.8, mobile phosphorus (according to Chirikov) 14.8 , and exchangeable potassium (according to Maslova) $-12.1 \mathrm{mg} / 100 \mathrm{~g}$ of the soil. In these soils, the neutral reaction of the soil environment and the content of available forms of sulfur for plants, it belongs to the middle group $(7.5 \mathrm{mg} / \mathrm{kg})$. In accordance with the laboratory tests, the content of micronutrients $(\mathrm{B}, \mathrm{Cu}, \mathrm{Zn})$ is typical for this type of soil and corresponds to the average group of availability. Dark gray wooded soils are characterized by a medium-loamy granulometric composition with an average organic matter content of about $3.1 \%$ and an acidic reaction of the soil environment $(\mathrm{pH} 5.1)$. They contain easily hydrolysable N 9.8, mobile P2O5, 11.3 and exchangeable $\mathrm{K} 2 \mathrm{O} 8.1 \mathrm{mg} / 100 \mathrm{~g}$ of soil. The content of mobile forms of sulfur is $2.9 \mathrm{mg} / \mathrm{kg}$ of soil. It refers these soils to the group of low-content sones with this nutrient.

It is known that the effectiveness of the cultivation of agricultural crops is greatly influenced by climatic conditions [1-9]. The amount and uniformity of precipitation, the best air temperature during the growing season have a considerable impact on the development of plants, the use of nutrients from the soil and applied fertilizers. This directly impacts the yield and quality of the resulting products. Table 2 presents the average meteorological data of the Kursk meteorological office over the years of the research. The average long-term precipitation rate in the experimental areas is $545 \mathrm{~mm}$, and the average long-term air temperature is about $5.6^{\circ} \mathrm{C}$. The analysis of temperature and precipitation data indicates that 
the climatic conditions in the years of our research (2018-2020) differed slightly from the long-term average data and can be characterized as normal for the weather conditions of the south-western Forest-steppe of the Central Black Earth Region.

Table 2. Weather and climatic conditions during research, 2018-2020, data obtained from the Kursk meteorological office.

\begin{tabular}{|c|c|c|c|c|c|c|c|c|}
\hline \multirow[t]{2}{*}{ Months } & \multirow{2}{*}{$\begin{array}{c}\text { Average } \\
\text { annual air } \\
\text { temperatur } \\
\text { e, }{ }^{\circ} \mathrm{C}\end{array}$} & \multicolumn{3}{|c|}{$\begin{array}{l}\text { Average monthly air } \\
\text { temperature, }{ }^{\circ} \mathrm{C}\end{array}$} & \multirow{2}{*}{$\begin{array}{c}\text { Average } \\
\text { annual } \\
\text { precipitation, } \\
\text { mm }\end{array}$} & \multicolumn{3}{|c|}{$\begin{array}{c}\text { Average monthly } \\
\text { precipitation by year, } \\
\mathrm{mm}\end{array}$} \\
\hline & & 2018 & 2019 & 2020 & & 2018 & 2019 & 2020 \\
\hline January & -10.0 & -4.9 & -6.4 & -1.1 & 34 & 35 & 53 & 22.2 \\
\hline February & -8.0 & -7.6 & -2.1 & -1.4 & 33 & 27 & 38 & 36.0 \\
\hline March & -2.9 & -5.6 & 1.3 & 4.0 & 32 & 74 & 56 & 18.1 \\
\hline April & 6.7 & 9.3 & 9.7 & 6.1 & 35 & 12 & 13 & 20.2 \\
\hline May & 13.8 & 17.8 & 16.8 & 11.9 & 50 & 43 & 73 & 74.1 \\
\hline June & 17.3 & 18.6 & 21.7 & 20.7 & 59 & 43 & 31 & 46.7 \\
\hline July & 18.9 & 20.4 & 18.7 & 21.0 & 71 & 180 & 49 & 72.6 \\
\hline August & 18.1 & 21.5 & 19.2 & 18.7 & 64 & 0 & 27 & 11.8 \\
\hline $\begin{array}{l}\text { Septembe } \\
\mathrm{r}\end{array}$ & 12.4 & 16.6 & 14.3 & 16.8 & 44 & 23 & 38 & 8 \\
\hline October & 6.4 & 8.8 & 9.5 & 11.1 & 41 & 22 & 57 & 27 \\
\hline November & 0.1 & -1.6 & 1.9 & & 41 & 6 & 41 & \\
\hline December & -4.3 & -5.0 & 0.2 & & 41 & 87 & 30 & \\
\hline Per year & 5.6 & 8.0 & 9.4 & & 545 & 603 & 528 & \\
\hline
\end{tabular}

The average monthly temperature in 2018 was $8.0^{\circ} \mathrm{C}$, which is 2.4 degrees higher than the long-term average. In 2019, a higher average monthly temperature was noted, which had a positive effect on the vegetation of grain crops. Among the temperature abnormalities, we can note the uncommonly warm winter of 2019-2020, when there were practically no subzero temperatures. According to the amount of precipitation in the years of the research, it can be seen that they were close to the average long-term norm. Nevertheless, the number of precipitation falls in the years of the study was very high.However, their distribution was extremely uneven. There is a pattern of minimal precipitation in August and September, which results in a lack of moisture in the autumn-spring period and impacted on the productivity of cultivated agricultural cultures.

For the optimization of soil capacity indicators and achieving a consistently high crop yield, the most significant factor is a balanced mineral nutrition. Moreover, most of them are currently introduced into the soil with mineral fertilizers and slightly with organic fertilizers $[1,9]$. While drawing up a complex system of nutrition of spring wheat plants, it is essential to consider what quantity of necessary nutrients of mineral nutrition will be available due to natural factors of soil capacity. This depends on many factors and the most relevant are: the number of mobile forms of nutrients in the soil, the forecrop, the farming standards in this enterprise, soil and climatic conditions, etc. It is essential to note that spring wheat is quite sensitive to the application of mineral fertilizers and makes considerable demands on soil capacity already in the initial stages of growth and development of spring wheat. Thus, in order to get maximum productivity, it is required to apply calculated doses of fertilizers, with the obligatory inclusion of meso- and micronutrients.

In performing field investigations on the effectiveness of sulfur-containing mineral fertilizers on spring wheat, concurrent monitoring was performed during the growing season. When applying fertilizers, the growth and development of plants became significantly more active. In these versions, a rapid onset of the phenological stages was detected. Generally, the stages of boot, ear formation and grain filling occurred for 2-4 days in comparison with 
the control. The stage of full ripeness of grain in the versions of mineral fertilizers application occurred 3 days later than in the control version. In accordance with the obtained data on the intensity of development of spring wheat plants in the experimental variants, it can be noted that there is no significant difference between usual and sulfur-containing fertilizers.

During our practical studies on the effectiveness of sulfur-containing fertilizers in the cultivation of spring wheat, the structure of the crop was defined. According to numerous practical data of leading researchers $[1,4,6]$, the future yield of grain crops is defined by the following three main indicators: tilling capacity, the number of grains per ear and the weight of 1000 grains. The data of field tests on the structure of the spring wheat crop of the Darya variety are given in Table 3.

Table 3. Indicators of the structure of the spring wheat crop, Kursk region, 2018-2020.

\begin{tabular}{|c|c|c|c|c|}
\hline Versions & $\begin{array}{l}\text { Number of } \\
\text { fertile stems } \\
\text { per } 1 \mathrm{~m}^{2}\end{array}$ & $\begin{array}{c}\text { Number of } \\
\text { grains per ear, } \\
\text { pcs. }\end{array}$ & $\begin{array}{c}\text { Weight of } \\
1000 \text { grains, } g\end{array}$ & $\begin{array}{c}\text { Grain-unit, } \\
\mathrm{g} / 1\end{array}$ \\
\hline \multicolumn{5}{|c|}{ Typical black soil } \\
\hline 1.Control & 491 & 27.1 & 28.5 & 761 \\
\hline 2. Ammonium sulfate in a dose N40S48 & 493 & $29.5-2.4$ & $31.9-3.4$ & $772-11$ \\
\hline 3. Ammonium nitrate in a dose $\mathrm{N} 40$ & 490 & $29.3-2.2$ & $31.7-3.2$ & $770-9$ \\
\hline 4.YaraVita THIOTRAC $30031+31$ & 491 & $27.5-0.4$ & $31.6-3.1$ & $769-8$ \\
\hline $\begin{array}{l}\text { 5. Fertilizer in a dose of N20P40K40S12+ } \\
\text { N20 }\end{array}$ & 495 & $29.4-2.3$ & $31.9-3.4$ & $770-9$ \\
\hline $\begin{array}{l}\text { 6. Fertilizer in a dose of N30P60K60S18 + } \\
\text { N30 }\end{array}$ & 497 & $29.8-2.7$ & $32.4-3.9$ & $772-11$ \\
\hline 7. Fertilizer in a dose of N40P40K40 & 492 & $29.3-2.2$ & $31.8-3.3$ & $769-8$ \\
\hline 8. Fertilizer in a dose of N60P60K60 & 494 & $29.7-2.6$ & $32.3-3.8$ & $770-9$ \\
\hline \multicolumn{5}{|c|}{ Dark gray wooded soil } \\
\hline 1.Control & 486 & 26.5 & 28.3 & 756 \\
\hline 2. Ammonium sulfate in a dose N40S48 & 488 & $28.9=2.4-0.6$ & $32.2-3.9-1.0$ & $768-12+4$ \\
\hline 3. Ammonium nitrate in a dose $\mathrm{N} 40$ & 489 & $28.3-1.8$ & $31.2-2.9$ & 764- 8 \\
\hline 4.YaraVita THIOTRAC $30031+31$ & 487 & $27.2-0.7$ & $31.0-2.7$ & $762-6$ \\
\hline $\begin{array}{l}\text { 5. Fertilizer in a dose of N20P40K40S12+ } \\
\text { N20 }\end{array}$ & 490 & $30.0-3.5+1.3$ & $32.5-4.2+1.0$ & $769-13+5$ \\
\hline $\begin{array}{l}\text { 6. Fertilizer in a dose of N30P60K60S18 + } \\
\text { N30 }\end{array}$ & 493 & $31.3-4.8+2.2$ & $32.8-4.5+1.2$ & $770-14+5$ \\
\hline 7. Fertilizer in a dose of N40P40K40 & 489 & $28.7-2.2$ & $31.5-3.2$ & $764-8$ \\
\hline 8. Fertilizer in a dose of N60P60K60 & 491 & $29.1-2.6$ & $31.6-3.3$ & $765-9$ \\
\hline
\end{tabular}

The obtained pilot data prove the positive effect of all applied fertilizers on the indicators of the crop structure. In black soils with an intermediate content of accessible sulfur, the performance of conventional complex fertilizers and sulfur-containing ones turned out to be practically the same. Moreover, practically equal indicators of the crop structure were found in the application of nitrogen fertilizers (ammonium sulfate and ammonium nitrate) for presowing cultivation. In applying YaraVita THIOTRAC 300 fertilizer with foliage spraying twice on the leaf surface, there was an increase in the mass of 1000 grains and the grain unit. The grain content in one ear increased to $2.7 \mathrm{pcs}$., the weight of 1000 grains raised to $3.9 \mathrm{~g}$., the grain nature increased to $11 \mathrm{~g} / 1$. The effect of sulfur-containing fertilizers on the structure of the spring wheat crop on black soils was low and was within the limits of the experimental error.

This yield formula on dark gray wooded soils indicates a higher efficiency of sulfurcontaining mineral fertilizers. The application of ammonium sulfate at a dose of N40S48 resulted in an increase in the number of grains in the ear to $2.4 \mathrm{pcs}$, the weight of 1000 grains raised to $3.9 \mathrm{~g}$, and the grain size increased to $12 \mathrm{~g} / \mathrm{l}$. Generally, the effectiveness of 
ammonium sulfate due to the sulfur included in its composition, if used on dark gray wooded soil, was considerably higher in comparison with ammonium nitrate in nitrogen-compatible doses. The composition of the crop in this case was considerably higher than when adding ammonium nitrate. Complex fertilizers with sulfur were also more efficient on dark gray wooded soil in comparison with usual fertilizers.

The received favorable data on the effectiveness of sulfur-containing fertilizers in the yield formula of spring wheat was certainly reflected to the main indicator-yield. During the cultivation of spring wheat in the conditions of the south-western Forest-Steppe, it is likely to further improve the yield due to the optimization of the fertilizer use system, and primarily through the introduction of meso and trace nutrients. Sulfur is one of these nutrients that has gained increasing attention in recent years. The data concerning the effect of various types of mineral fertilizers on the yield of spring wheat in the field experiments are presented in Table 4.

Table 4. Spring wheat yield by experience variants, Kursk region, 2018-2020.

\begin{tabular}{|c|c|c|c|c|c|c|}
\hline \multirow[t]{2}{*}{ Versions of the experiment } & \multicolumn{3}{|c|}{ Yield by year, c / ha } & \multirow{2}{*}{$\begin{array}{c}\text { Average } \\
\text { yield, c / } \\
\text { ha }\end{array}$} & \multicolumn{2}{|c|}{$\begin{array}{l}\text { Yield increase, } \mathrm{c} / \\
\text { ha }\end{array}$} \\
\hline & 2018 & 2019 & 2020 & & $\begin{array}{c}\text { from } \\
\text { mineral } \\
\text { fertilizers }\end{array}$ & $\begin{array}{l}\text { from } \\
\text { sulfur }\end{array}$ \\
\hline \multicolumn{7}{|c|}{ Black soils } \\
\hline 1.Control & 35.5 & 38.2 & 39.3 & 37.7 & - & \\
\hline 2. Ammonium sulfate in a dose N40S48 & 41.3 & 43.7 & 44.2 & 43.0 & 5.3 & -0.3 \\
\hline 3. Ammonium nitrate in a dose $\mathrm{N} 40$ & 41.8 & 42.8 & 45.3 & 43.3 & 5.6 & \\
\hline 4. YaraVita THIOTRAC $30031+31$ & 37.8 & 41.6 & 42.7 & 40.7 & 3.0 & \\
\hline $\begin{array}{l}\text { 5.Fertilizer in a dose of N20P40K40S12+ } \\
\text { N20 }\end{array}$ & 42.7 & 46.1 & 49.7 & 46.2 & 8.5 & 1.3 \\
\hline $\begin{array}{l}\text { 6. Fertilizer in a dose of N30P60K60S18 } \\
+\mathrm{N} 30\end{array}$ & 46.1 & 50.8 & 55.6 & 50.8 & 13.1 & 0.8 \\
\hline 7. Fertilizer in a dose of N40P40K40 & 41.1 & 44.5 & 49.1 & 44.9 & 7.2 & \\
\hline 8. Fertilizer in a dose of N60P60K60 & 45.4 & 50.0 & 54.8 & 50.0 & 12.3 & \\
\hline HCP 05 (c/ha) & 2.0 & 2.4 & 2.4 & 2.3 & & \\
\hline \multicolumn{7}{|c|}{ Dark gray wooded soils } \\
\hline 1.Control & 33.0 & 35.4 & 37.5 & 35.3 & & \\
\hline 2. Ammonium sulfate in a dose N40S48 & 39.5 & 41.2 & 44.8 & 41.8 & 6.5 & 1.5 \\
\hline 3. Ammonium nitrate in a dose $\mathrm{N} 40$ & 37.8 & 40.3 & 42.7 & 40.3 & 5.0 & \\
\hline 4.YaraVita THIOTRAC $30031+31$ & 38.4 & 41.0 & 43.3 & 40.9 & 5.6 & \\
\hline $\begin{array}{l}\text { 5.Fertilizer in a dose of N20P40K40S12+ } \\
\text { N20 }\end{array}$ & 41.4 & 44.3 & 46.7 & 44.1 & 8.8 & 2.4 \\
\hline $\begin{array}{l}\text { 6. Fertilizer in a dose of N30P60K60S18 } \\
+\mathrm{N} 30\end{array}$ & 44.0 & 48.9 & 51.1 & 48.0 & 12.7 & 2.8 \\
\hline 7. Fertilizer in a dose of N40P40K40 & 40.1 & 41.7 & 43.4 & 41.7 & 6.4 & \\
\hline 8. Fertilizer in a dose of N60P60K60 & 42.3 & 45.1 & 48.2 & 45.2 & 9.9 & \\
\hline HCP 05 (c/ha) & 1.8 & 1.9 & 2.1 & 1.9 & & \\
\hline
\end{tabular}

Received data from field trials conducted in the Kursk region indicate that they had a significant positive effect on increasing the yield of spring wheat in all versions of the experiment. As expected, black soils have gained a higher yield over the years of research compared to dark gray wooded soils. This can be accounted for by the higher content of the forms of nutrients affordable for plant nutrition. In the version of applying fertilizers at a dose of $\mathrm{N} 40 \mathrm{P} 40 \mathrm{~K} 40 \mathrm{~kg}$ / ha on the black soils, the yield rose on average for three years by $7.2 \mathrm{c} /$ ha, and in the dose of N60P60K60 by $12.3 \mathrm{c} /$ ha in comparison with the control version. Complex mineral fertilizers in the same doses, but with the introduction of sulfur, S12 and $\mathrm{S} 18$, respectively, in the fifth and sixth versions increased the yield by 8.5 and $13.1 \mathrm{c} /$ ha in comparison with the control. The growth due to the application of sulfur was reached in 1.3 
and $0.8 \mathrm{c} / \mathrm{ha}$. The application of ammonium nitrate at a dose of N40 gave an addition of 5.6 c / ha and was more efficient than ammonium sulfate on black soils. The use of foliage spraying YaraVita THIOTRAC 300 at a dose of $31+31$ showed an increase of $3 \mathrm{c} /$ ha, which is significantly worse than all other fertilizers. There was no considerable advantage of sulfurcontaining fertilizers over usual ones on typical black soils.

The application of sulfur-containing fertilizers has proved to be more effective on dark gray wooded soils. Ammonium sulfate with an increase of $6.5 \mathrm{c} /$ ha was $1.5 \mathrm{c} /$ ha more efficient than ammonium nitrate in equal nitrogen doses of $40 \mathrm{~kg} / \mathrm{ha}$. The application of YaraVita THIOTRAC 300 at a dose of $31+31$ provided an addition of $5.6 \mathrm{c} /$ ha comparing to the control, which is almost twice as high as the indicator obtained on the black soils. The use of complex sulfur-containing fertilizers also demonstrated higher efficiency compared to usual ones. The application of NPKS at a dose of N20P40K40S12 + N20 provided an uptick of $8.8 \mathrm{c} /$ ha in comparison with the control. This is $2.4 \mathrm{c} /$ ha higher than the non-sulfur version. If the fertilizer dose is raised to N30P60K60S18 + N30, the highest yield is received. The increase was $12.7 \mathrm{c} /$ ha compared to the control, which is $2.8 \mathrm{c} /$ ha higher than in the non-sulfur version. This indicates that in soils with a low sulfur content, the use of sulfurcontaining fertilizers has a considerable impact on the yield of spring wheat.

\section{Conclusion}

1. In the arable soils of the Central Black Earth Region, the supply of one of the most essential nutrients, sulfur, decreases every year. Today, in the Kursk region, about $87 \%$ of the total area of arable land has a low provision of this nutrient. Thus, in the technologies of cultivation of agricultural crops, the introduction of sulfur with mineral fertilizers becomes one of the necessary factors to get a consistently high yield.

2. In the cultivation of spring wheat, the effectiveness of the use of sulfur-containing mineral fertilizers mainly depends on the content of this nutrient in the soil. In the black soils with an intermediate supply of sulfur, the use of sulfur-containing fertilizers has almost no advantages in comparison with the usual fertilizers without sulfur. In soils with a low supply of affordable forms of sulfur (dark gray wooded soils), the use of sulfur-containing fertilizers is much more efficient in comparison with fertilizers without sulfur.

3. The application of sulfur-containing fertilizers influences the formation of nutrients in the structure of spring wheat crop. In the black soils with an intermediate content of affordable sulfur, the performance of conventional complex fertilizers and sulfur-containing ones turned out to be practically the same. These crop structures on dark gray wooded soils indicate a higher performance of sulfur-containing mineral fertilizers. Introduction of ammonium sulfate at a dose of N40S48 raised the number of grains in the ear to 2.4 pcs, the weight of 1000 grains rose to $3.9 \mathrm{~g}$, and the grain size grew to $12 \mathrm{~g} / \mathrm{l}$.

4. Over the years of research, mineral fertilizers have considerably enhanced the yield of spring wheat. In this case, the highest yield was achieved on the black soils, which have a higher supply of available nutrients. The application of sulfur-containing mineral fertilizers on these soils, which have an average content of mobile sulfur, has a small impact on growing the yield of spring wheat. It is similar to the use of usual fertilizers without sulfur.

5. The highest effect of sulfur-containing fertilizers was achieved on soils with a low content of accessible forms of sulfur (dark gray wooded soils). The use of sulfur fertilizers on these soils had a considerable impact on the yield of spring wheat and ensured an additional $2.4 \mathrm{c} /$ ha when applying N40P40K40S12, and $2.8 \mathrm{c} /$ ha when applying N60P60K60S18, in comparison with the use of the same doses of mineral fertilizers without sulfur. The introduction of ammonium sulfate was $1.5 \mathrm{c} /$ ha more efficient than ammonium nitrate. Moreover, the application of YaraVita THIOTRAC 300 at a dose of $31+31$, which ensured a $5.6 \mathrm{c} /$ ha grain boost compared to the control, is promising on these soils. 


\section{References}

1. V.I. Lazarev, Zh. N. Minchenko, A. Ya. Bashkatov, Th. \& Appl. Ec, 3, 153-159 (2020) doi: 10.25750/1995-4301-2020-3-154-160

2. A. Yu. Aidiev, I.A. Zolotareva, L.V. Levshakov, Bul. of the Rus. Ac. of Agri. Sc, 4, $25-$ 27 (2009)

3. L.V. Levshakov, Bul. Of Kur. St. Ag. Ac, 3, 51-53 (2011)

4. I.Ya Maslova, T.G. Yakusheva, Agrochem, 7, 22-32 (2004)

5. A.V. Chevychelov, L.V. Levshakov, V.I. Lazarev, Int. Agr. J, 4, 51-54 (2019)

6. A. Kh. Sheudzhen. The physiological role of sulfur in plant life. Fertilizer and growth controllers in rice crops, Krasnodar, 36-41 (2002)

7. C.A. Grant, Can. J. Plant Sci, 83 (4), 745-758 (2003)

8. A. Kh. Arisratkhov, Agrochemistry of sulfur, VNIIA, Moscow, 272 (2007)

9. L.V. Levshakov, A.V. Chevychelov, Bul. Of Kur. St. Ag. Ac, 1, 53-58 (2016)

10. V. A. Kholodov, Yu. R. Farkhodov, N. V. Yaroslavtseva, A. Yu. Aydiev, V. I. Lazarevc B. S. Ilyin, A. L. Ivanov, and N. A. Kulikova, Ev. S. Sc, 8, 970-982 (2020)

11. V.I. Lazarev, A.V. Chevychelov, Zeml, 5, 29-32 (2016)

12. L.V. Levshakov, A.V. Chevychelov, V.I. Lazarev, M.A. Pyatkov, Bul. Of Kur. St. Ag. Ac, 7, 58-65 (2019)

13. B.A. Dospekhov. Field test methodology, Agrompizdat, Moscow, 351 (1985) 